\title{
Health and Social Problems in Indonesian Elderly. How Can Health Care System To Overcome?
}

\author{
Iwan Rusdi \\ Department of Geriatric, Faculty of Nursing, Universitas Sumatera Utara
}

\begin{abstract}
Increasing elderly population is a problem in Indonesia. Many problems faced in elderly. Elderly are high risk to experience a disease or illness. As well as, long term care is needed for release the disease. A changing in biopsychosocial also important for service provider to control the effect. Collaboration and partnerships is useful to develop strengthening in creating health care system. Furthermore, policy maker and service provider are also better able to review and refine their existing measure, policies, product and geriatric service, which target elderly population in Indonesia.
\end{abstract}

Keywords: Health, Social Problem, Elderly, Health Care System.

Received 21 November 2019 | Revised 23 December 2019| Accepted 29 December 2019

\section{Introduction}

The increasing elderly population in Indonesia has been faced now. It can cause a problem for the government in manage their health. Biro Pusat Statistik (2017) reported that the population of elderly $8,97 \%$ ( 23,4 millions). Instead, a ratio elderly population higher than children $(8.97 \%$ $: 8.95 \%$ ). Now Indonesia is going to aged demography structure. It is high risk for rising a new problem if not be solved. Many problem will raise relating to process in elderly.

As a process of aging, many changing happen such as; physic, psychology, social and spiritual. Based on studied by Ministry of Health (2018) reported that many problem in elderly health such as: heart disease, stroke, diabetes mellitus, rheumatic and injuries. Theirs changing can make depression. Depresion is one of multifactor phenomenon in elderly that is influenced by biopsychosocial. It is supported by Gloria, et al (2011) that fall, memory problem, lower perceived health, and low education were associated with depression in elderly. In addition, Haya et al (2015) reported that Diabetes mellitus may influence the rate of functional decline among patient with alzeimer disease dementia.

\footnotetext{
*Corresponding author at: Jl. Prof.Maas No. 03 Kampus USU, Medan, Indonesia.

E-mail address: iwan.rusdi@gmail.com
} 
With age, older individual will be suffering because of greather number of chronic illness. Consequently, they faced negative affects from these conditions. Finally they are declining well being, functional disability and poor health assessment. Supported by Ministry of Health (2018) reported that elderly have got disability around $19.1 \%$ for Men and $24.7 \%$ for women. It can be more effect to their life. In addition, quality of life will decrease along with aging.

In generally, elderly stays with their suppose, because of the culture of Indonesian. As well as, the family have to support living cost and health care. In fact, elderly do not has income related to their condition. It become social problem issue in Indonesia. To carried out these problems, the government has to develop health care system to accommodate changing to avoid its effect of growing the elderly now and the future. Regarding to BPJS (2017) reported that there were increasing number of elderly stay with their family (24.5 to $26.35 \%$ ). Based on these conditions that growing elderly in Indonesia will be effected to developing nation and need some system to treat its.

\section{Literature Search}

This articles is based entirely on secondary research. It is from government publications focus on health care in elderly and also another publication related to health issues.

\section{Result and Discussion}

To avoid effect of growing of elderly in Indonesia, the government have been produced many of policy in term to manage elderly. In the past decade, the government had make policy for elderly. It is developed on preventive, promotion in area community. Nevertheless, now changing in population of elderly, the government have to challenge its. Based on National Health System (NHS), there are many factors can contribute in order to overcome the problem in elderly. The components of system must collaborate by partnership intra or inter program for elderly.

In term to conditions, Act of elderly number 13 in 1998 has been supported for social welfare of elderly, such as social assist, and social support. These are important for elderly in helping their life. However, it is only helping elderly with social problems. Supported by ministry of social (2018) reported that the act of elderly number 13 in 1998 have to revise because some of elderly right are not fulfill yet.

Ministry of Health have been supported to improve health of elderly, act of ministry of health number 25 in 2016 about National Planning Action for Elderly Health 2016 - 2019 (RAN Lansia). Ministry of Health (2016) reported that RAN Lansia can earn healthy elderly, independent, active, productive and beneficial for family and community. It is expected to increase quality of services and accessibility for elderly. Target of RAN Lansia are direct and 
indirect target. Direct target include; pre elderly (45 - 59 years), elderly (60 - 69 years), high risk (more than 70 years) and with health problem. However, infirmity of RAN Lansia include service facilities geriatric are not ready yet such as hospital, community health center, and community health facilities. In addition, the awareness of elderly health in community is low. Based on this situation, government have to create a available program in order to promote elderly program in Indonesia.

To implement programs, recently the government have been published a act of Ministry of Health about implementation of geriatric services in Hospital. Ministry of Health (2014) reported that the implementation of geriatric services include kind of services such as; professional resource, professional interrelationship, services standard and infrastructure. Furthermore, it can be facilitating to solve a problem of elderly in the future. In the past geriatric services are community oriented. However, now have been changed a long with changing demographic structure in elderly. The government have been awareness for its. Supporting from Indonesian Hospital Association (2018) reported that geriatric services in hospital include in standard accreditation of hospital. Furthermore, it will be benefit for promoting elderly health. In addition, Ministry of Health (2014) explained that geriatric service also implement in three categories such as ; community based geriatric service, hospital based community geriatric service and hospital based geriatric service. These categories are important to help elderly or community in access health care.

Another attention, health cost is one aspect that can influence health status for the individual especially elderly. It is caused by elderly who got a chronic illness. Chronic illness need attention because long treatment or long term care. Its need high cost for recovery. BPJS or National Health Insurance is one of institution that manage health cost by government. In the past the cost of health insurance is supported by government and now also have suffer in health cost. Howerver, now people have to pay itself by participating in member of BPJS. As mention before, that health cost in elderly people is highest because cost of long term care is not covered by BPJS. Furthermore, to maintain their need for health and life, Ministry of Social (2018) reported that elderly with poverty, unattended, social problem, and physical problem are supported by government. In term of health cost, need to awareness of elderly and community for health insurance. As well as government have to create system to manage health insurance focus on elderly. Supported by Chiyoe (2010) reported that Japan has reformed health care cost and increasing the efficiency of health care. Indonesia will be a nations with highest elderly population same as Japanese.

\section{Conclusion and Suggestion}

Increasing elderly population can effect to many aspects. Aging process is a normal condition. However, elderly are high risk to experience a disease or illness. It will be increasing health cost 
to cure or maintain their health. Developing health care system by government are needed in order to minimize the effect. The government have been tried to overcome with policy in many institutions. However, collaboration and partnership have to develop, it is for awareness of health in individual, family, community and institution. In term of long term care, health insurance for elderly have to refine to be appropriated with elderly population. As well as policies of geriatric service is needed.

\section{REFERENCES}

[1] Badan Pusat Statistik. (2017). Statistik Penduduk Lanjut Usia 2017 Di akses melalui http://www.bps.go.id.

[2] Chiyoe et. al. (2010). Barriers to Health Careamong the Elderly in Japan. International Journal Environmental Reasearch and Public Health, 7, 1330-1341.

[3] Gloria, et al. (2011). Depressive Symptoms in Old Age: Relation among sociodemographic and self- Reported Health Variables. International Psychogeriatrics. 23: 6, 941-949.

[4] Haya et. al. (2015). Cognitive and Functional Decline in Patient with Mild Alzheimer Dementia Disease with or without Comorbid Diabetes. Clinical Therapeutics, Vol 7, 6, 2015.

[5] PDPERSI. (2018). Standard Nasional Akreditasi Rumah Sakit edisi 1. Diakses melalui

http://www.pdpersi.co.id/kanalpersi/manajemen_mutu/data/snars_edisi1.pdf.

[6] Kemsos. (2018). Peraturan Menteri Sosial No 5 tahun 2018 Tentang Standard Nasional Rehabilitasi Sosial Lanjut Usia. Di akses melalui http://www.dokhuk.kemsos.go.id/sisdok/

[7] Kemsos. (2018). Undang - undang No 13 tahun 1998 Teentang Kesejahteran Lanjut Usia Perlu di Revisi. Pemenuhan Hak lansia Usia belum Di Akomudir. Di akses melalui https://www.kemsos.go.id/berita/undang-undang-no-13-tahun-1998.

[8] Kemkes. (2018). Hasil Utama Riskesdas 2018. Di akses melalui http:// www.depkes.go.id/resources.

[9] Kemenkes. (2016). Peraturan Menteri Kesehatan No 25 Tahun 2016 Tentang Rencana Aksi Nasional Kesehatan lanjut Usia tahun 2016 - 2019. Di akses melalui http://kesga.kemkes.go.id/images/pedoman/PMK\%20.

[10] Kemenkes (2014). Peraturan Menteri Kesehatan Republik Indonesia Nomor 79 tahun 2014 Tentang Penyelenggaraan Pelayanan Geriatri di Rumah Sakit. Di akses melalui http://bprs.kemkes.go.id/v1/uploads/pdffiles/peraturan/47 PMK No. 79 ttg Penyelenggaraan Pelayanan Geriatri di RS.pdf. 